\title{
Flipped Classroom Method with Computer- Assisted Language Learning (CALL) in EFL Writing Class
}

\author{
M. Ali Ghufron \\ IKIP PGRI Bojonegoro, East Java, Indonesia \\ https://orcid.org/0000-0003-0681-9140 \\ Fitri Nurdianingsih \\ IKIP PGRI Bojonegoro, East Java, Indonesia \\ https:// orcid.org/0000-0001-9806-7761
}

\begin{abstract}
This study revealed the strengths, weaknesses, and effectiveness of the flipped classroom with CALL in EFL writing class. A mixed-method approach was used to achieve the goals of the study. An embedded quasi-experimental methodology design was used to achieve the aims of this study (i.e., quantitative and qualitative data analysis). There were a hundred and fifty Indonesian EFL university learners who participated in this study. This study also involved 14 EFL writing teachers who experienced implementing the flipped classroom with CALL from five universities. The results of this study revealed that a flipped classroom with CALL in EFL writing class has many advantages, such as stimulating learner autonomy, improving teaching and learning processes, providing more time for EFL writing and input during face-toface meetings, promoting active learning, student learning responsibility, and peer collaboration. Besides, some drawbacks were also found from its implementation. However, implementing the flipped classroom in the current study positively affects the EFL writing course. This study implies that teachers can include online resources such as videos from reputable sources or make their videos as learning materials if possible.
\end{abstract}

Keywords: CALL; EFL writing; Flipped classroom; mixed-method approach

\section{Introduction}

The flipped classroom is a form of learning in which homework and preparation are modified, and learning occurs outside the classroom (Adnan, 2017; Bergmann, J., \& Sams, 2012; Chen Hsieh, Wu \& Marek, 2017; Karabulut-Ilgu, Jaramillo Cherrez \& Jahren, 2018). According to Chen Hsieh et al., (2017), the new information is transmitted to students, mostly through videos, in the flipped classroom when they leave school. Students engage in realistic exercises and procedures under the 
supervision of teachers at the school. A flipped classroom offers the ability to involve students actively and fosters an engaging learning atmosphere (Chuang, Weng \& Chen, 2018). Before classes, videos are made available to students to learn at their speed (Chen Hsieh et al., 2017; Yu \& Wang, 2016). The time for teaching is flexible in a flipped classroom, a vivid and engaging learning atmosphere is developed, and concepts can be detailed (Amiryousefi, 2017; Chen Hsieh et al., 2017; Francl, 2014). The flipped classroom also leads to better academic performance and reduces students' cognitive pressure (Turan \& Göktaş, 2018), and improves students' participation (Chen Hsieh et al., 2017).

It is already known that learning a foreign language takes time, needs patience, and requires many exercises. For successful foreign language learning outcomes, students should be encouraged to actively participate in more learning activities to understand the target language better. Thus, due to insufficient time, teachers will be compelled to skip the core facets of active foreign language learning. Han (Han, 2015) suggests that the flipped classroom will contribute to language learning results by extending teaching outside the classroom and providing extra classroom activities. The paradigm of the flipped classroom is found useful in language learning because it encourages two main points of success, i.e., studentcentered learning and learner autonomy (Amiryousefi, 2017; Ghufron \& Nurdianingsih, 2019, 2020; Han, 2015; Köroğlu \& Çakır, 2017). According to Chen Hsieh et al., (2017), the flipped classroom method provides an appropriate learning environment with certain ELT benefits.

Writing in a foreign language, as a productive skill, is pivotal as learners are required to achieve an appropriate level of competence in written communication. New language learning and teaching methods enhance communication within this context, so writing skills must be learned as much as possible in language classes. However, teachers are urged to revisit their teaching practices in classrooms where students have minimal opportunity to learn target languages to reduce their challenges and build more fun, inspiring, and self-reliant lessons (Ekmekci, 2017). In this sense, teachers of foreign languages should use technology in their classrooms (Purcell, Buchanan \& Friedrich, 2013).

One strategy to facilitate teachers' instruction is to incorporate computer-assisted language learning (Alhasani, Masood \& Wan, 2018). CALL has demonstrated its efficacy through previous studies in English language teaching and learning (Jafarian, Soori \& Kafipour, 2012; Rahimi \& Hosseini K., 2011; Talebinezhad \& Abarghoui, 2013). Integrating CALL with the flipped classroom method can make the learning process to be moved to any location with Internet or $\mathrm{Wi}-\mathrm{Fi}$ connection. Therefore, the term 'classroom' becomes borderless in this context (Webb et al., 2014). Flipped classroom with CALL uses technology to improve student autonomy and learning control (Webb \& Doman, 2020).

Some experiments on the flipped classroom implementation with CALL in English language teaching have been conducted (Adnan, 2017; Ahmad, 2016; AlHarbi \& Alshumaimeri, 2016; Arifani, 2019; Doman \& Webb, 2017; Han, 2015; Sung, 2015). Adnan (2017) investigated the perceptions of ELT students in the flipped classroom. The findings show no substantial difference between the two 
groups in e-portfolios, but the flipped students' scores were substantially improved compared to non-flipped students. The findings also indicate students' positive perceptions and satisfactory experiences of learning. Ahmad (2016) explored the flipped classroom method's influence on the listening comprehension of Egyptian EFL students. The result indicates that the flipped classroom positively affects the Egyptian EFL students' listening comprehension. Al-Harbi and Alshumaimeri (2016) analyzed the flip strategy to explore its effect on the results, expectations, and attitudes of secondary school students in the Saudi context. The results show that the flipped classroom can enhance EFL students' grammar mastery, and the students also responded positively to the flipped classroom implementation. Arifani (2019) has investigated the WhatsApp group and individual flipped classrooms' impact to help EFL students' mastery in collocation. The findings show that WhatsApp group activities resulted in better collocation mastery than individual WhatsApp activities. Learners who were taught with the small group flipped instruction through WhatsApp with small group collocation activities show more positive attitudes than the individual WhatsApp activities. Sung (2015) researched flipped classrooms on EFL content courses. The findings have shown that given initial difficulties in adapting to the flipped classroom, the students have positively seen the flipped approach. In addition, they considered flipped teaching to be the driving force for the current ELT. From the previous studies, however, there has been little study investigating the strengths, weaknesses, and effectiveness of the flipped classroom method with CALL in EFL writing class, especially in the Indonesian context.

This study evaluates the strengths, weaknesses, and effectiveness of flipped classrooms with CALL in EFL writing classes to fulfil the previous studies' gaps. Several English teachers and students from private and state universities in Indonesia who have implemented flipped classrooms with CALL in EFL writing courses were involved in this study. Those participants used some platforms while implementing flipped classrooms, such as YouTube videos, weblogs, and other Learning Management Systems (LMS). Some of them also used Google docs integrated with an automated feedback program as their media in EFL writing. From the elaboration above, the research questions (RQs) are formulated as follows. (1) What are the strengths of the flipped classroom with CALL in the EFL writing class? (2) What are the weaknesses of the flipped classroom with CALL in the EFL writing class? (3) Is there any significant difference in students' EFL writing performance before and after implementing the flipped classroom with CALL?

Dealing with the third research question, since it is a quantitative question, it has a hypothesis which is stated as follows. $\mathrm{H}_{0}$ : There is no significant difference in students' EFL writing performance before and after implementing the flipped classroom with CALL; $\mathrm{H}_{1}$ : There is a significant difference in students' EFL writing performance before and after implementing the flipped classroom with CALL. 


\section{Literature Review}

Several studies are investigating the flipped classroom in the ELT context. From those studies, it was revealed that there are four major trends of flipped classroom studies in the ELT context, i.e., the flipped classroom on EFL/ESL skills, its advantages on FL/ESL, the challenges of its implementation in ELT, and its effectiveness in ELT (Turan \& Akdag-Cimen, 2019).

The first trend is the flipped classroom implementation on English language skills (Ahmad, 2016; Al-Harbi \& Alshumaimeri, 2016; Ekmekci, 2017; Huang \& Hong, 2016; Köroğlu \& Çakır, 2017; Soltanpour \& Valizadeh, 2018; Su Ping et al., 2019; Vaezi et al., 2019; Zou \& Xie, 2019). Studies on the flipped classroom implementation were overwhelmingly positive. Vaezi, Afghari \& Lotfi, (2019) investigated the flipped classroom's impact on students' listening comprehension. The results of this study demonstrated that flipped teaching enhanced students' listening achievement. Köroğlu and Çakır (2017) examined the effects of the flipped classroom on the English-speaking skills of pre-service teachers. The study's findings showed that the flipped classroom is efficient for developing English-speaking skills in pre-service teachers. Furthermore, flipped teaching improves fluency and clarity, lexical capital, grammatical precision, and pronunciation among language students. Huang and Hong (2016) have investigated the impact of a flipped English-Classroom Approach on high school students' English-learning and ICT skills in Taiwan. The study's findings showed that the Flipped English classroom technique is effective when used for high school students. It fosters independence and grounds for learning English literacy. Furthermore, teacher-student interactions were successful in developing student ICT skills. Zou and Xie (2019), proposed a flipped learning model and explored its usefulness in supporting writing skills. Results showed that in writing performance, flipped learning outperformed traditional flipped learning. The suggested flipped learning paradigm should be used in more English writing courses. From previous research, it can be inferred that introducing the flipped classroom has a beneficial impact on English language skills.

The second trend is about the advantages and the strengths of the flipped classroom in ELT (Alsowat, 2016; Amiryousefi, 2017; Basal, 2015; Boyraz \& Ocak, 2017; Choe \& Seong, 2016; Gasmi, 2017; Zainuddin, 2017; Zainuddin \& Perera, 2017). Some scholars have conducted several studies investigating the advantages and the strengths of the flipped classroom in the ELT context. One of them is the study conducted by Amiryousefi (2017). He studied the impact of flipped learning on speaking, listening, out-of-class engagement, and involvement in ESL students' courses and activities. Telegram instant messaging has been chosen as the online forum for organized, semi-structured, and flipped learning groups to collaboratively carry out the preparatory works. The results suggest that flipped learning can create a less disruptive educational experience than traditional environments. It will create resources for more cooperative and interactive learning experiences, expand input and performance boundaries, and improve opportunities for high-quality engagement. Boyraz \& Ocak (2017) carried out a review to look for an impact on the academic success of students in the Flipped Classroom (FC) and to maintain EFL awareness and to acquire opinion on this 
new approach. The results reveal that FC is very helpful in encouraging students to learn words and concepts outside of their classroom and in solving students' problems either individually or in groups with the teacher's encouragement and involvement inside the classroom. Moreover, the integration of technological elements in FC could boost students' learning motivation. The other advantages of the flipped classroom are also investigated, such as enhancing learners' preparedness (Choe \& Seong, 2016), lowering learners' nervousness (Chen Hsieh et al., 2017), promoting learners' in-depth learning strategies (Gasmi, 2017), improving learners' ICT skills (Huang \& Hong, 2016), etc.

The third trend is about the flipped classroom implementation challenges in ELT (Ansori \& Nafi', 2018; Egbert, Herman \& Lee, 2015; Ghufron \& Nurdianingsih, 2019, 2020; Yang, 2017; Zhang, 2017). A study conducted by Egbert et al., (2015) revealed that technology/internet related problems are a challenge for both instructors and learners during the flipped classroom implementation. Besides, Yang (2017) discussed the introduction of an English-language flipped classroom in Hong Kong. Findings suggest that flipping a classroom will only benefit more inspired learners and that an additional workload is required for learners to attend the flipped classroom session. Further, Zhang (2017) also confirmed that the flipped classroom causes an extra workload for learners and teachers. He argues that a flipped classroom is a type of instruction that pays more attention to self-learning and teaching. The best way to improve the teaching effect is to manage pre-class and in-class time. Students must prepare well in their pre-class studies. In classrooms, teachers must continuously direct students to learn and help them overcome their learning problems and supervise them to complete their learning tasks and objectives.

The fourth trend is about the effect of the flipped classroom in ELT (Kang, 2015; Khosravani, Khoshsima \& Mohamadian, 2020; Meléndez \& Iza, 2017; Mo \& Mao, 2017; Rahmelina et al., 2019; Suranakkharin, 2017; Yu \& Wang, 2016). Most studies investigating the flipped classroom's effectiveness confirm that the method is effective to be implemented in the ELT context (Ahmad, 2016; Alsowat, 2016; Amiryousefi, 2017; Meléndez \& Iza, 2017; Mo \& Mao, 2017). However, a few studies also reveal that the flipped classroom is not effective (Al-Harbi \& Alshumaimeri, 2016; Suranakkharin, 2017). Al-Harbi and Alshumaimeri (2016) applied the flipped classroom method in English grammar class. The research investigated whether or not the flipped classroom substantially influences English grammar achievements by experimental and control groups. The results confirm that there is no significant difference in English grammar achievements between the students who were in the experimental and control groups. Furthermore, Suranakkharin (2017) investigates the flipped classroom's effect on students' English collocation knowledge compared to traditional instruction in the Thai context. In general, the results indicate that after introducing the flipped classroom, student collocation learning outcomes improved significantly. However, the results also indicate that there was no significant difference between the flipped and traditional classrooms. 
In summary, this study also supports the previous theories and studies which investigate flipped classroom in line with the major research trends that were previously described. This study was focused on, not only investigating the strengths and weaknesses of the flipped classroom method in EFL writing context, but also its effectiveness when it is integrated with computer system as an assisting tool in teaching and learning process. This study benefits the scholars, educators, and policy makers who focus on English language teaching and also those who focus on the integration of e-media in teaching and learning process.

\section{Methodology}

\subsection{Research Goal}

From the RQs above, the goals of this study were (1) revealing the strengths of the flipped classroom with CALL in EFL writing class, (2) revealing the weaknesses of the flipped classroom with CALL in EFL writing class, and (3) revealing whether or not there is a significant difference in students' EFL writing performance before and after the implementation of the flipped classroom with CALL.

\subsection{Research Design}

A mixed-method approach was used to achieve the goals of the study. The concept of mixed-methods relates to an emerging research approach that promotes systematic integration or a combination of quantitative and qualitative data in a single study or sustainable research (Wisdom \& Creswell, 2013). The design is based on the assumption that a single data set is not adequate to answer multiple research questions (Creswell \& Clark, 2011). Therefore, an embedded quasi-experimental methodology design was used to achieve the aims of this study (i.e., quantitative and qualitative data collection and analysis).

\subsection{Research Participants and Context}

There were a hundred and fifty Indonesian EFL university learners who participated in this study. They were enrolled in five English Education Programs at some private and state universities situated in the East and Central Java. All the participants took EFL writing course as a compulsory course in the English education curriculum. Each university was represented by one class consisted of thirty students. The chosen class in each university was chosen by using a cluster random sampling technique. Besides, the researchers also used a purposeful sampling method for an in-depth interview. The willingness to be interviewed and the availability of the participants influenced the sampling process.

In the chosen class, the students were treated using the flipped classroom with CALL in their EFL writing class in one semester (a 14-week intervention). Before any treatment, the students were given a pretest in the form of a 500-word essay writing of expository texts with the free topic. Once the treatment had been completed, the students were given a post-writing test to write 500-word expository texts with the free topic. Both the pre and posttest were performed individually through google docs media. 
Furthermore, this study also involved 14 EFL writing teachers who experienced implementing the flipped classroom with CALL from five universities. Those teachers were chosen purposively based on some criteria, i.e., having at least onesemester experience implementing the flipped classroom with CALL in an EFL writing class, having a commitment and willingness to participate in the study from the beginning until the end.

\subsection{Methods of Data Collection and Instruments}

The data were collected through questionnaires, in-depth interviews, and tests (pre and posttest) to achieve this study's purposes. The detailed information of data collection methods is presented in table 1.

Table 1: Purposes of the Study and Data Collection Methods

\begin{tabular}{|l|l|l|}
\hline No. & \multicolumn{1}{|c|}{ Purposes of the Study } & \multicolumn{1}{c|}{$\begin{array}{c}\text { Data Collection } \\
\text { Methods }\end{array}$} \\
\hline 1 & $\begin{array}{l}\text { Revealing the strengths of the flipped } \\
\text { classroom with CALL in EFL writing class }\end{array}$ & $\begin{array}{l}\text { Questionnaires \& in-depth } \\
\text { interviews }\end{array}$ \\
\hline 2 & $\begin{array}{l}\text { Revealing the weaknesses of the flipped } \\
\text { classroom with CALL in EFL writing class }\end{array}$ & $\begin{array}{l}\text { Questionnaires \& in-depth } \\
\text { interviews }\end{array}$ \\
\hline 3 & $\begin{array}{l}\text { Revealing whether or not there is a significant } \\
\text { difference in students EFL writing } \\
\text { performance before and after the } \\
\text { implementation of the flipped classroom with } \\
\text { CALL }\end{array}$ & Pre \&osttest \\
\hline
\end{tabular}

The first data collection method is the distribution of questionnaires. There were two types of questionnaires focusing on revealing the flipped classroom's strengths and weaknesses, i.e., students' survey and teachers' survey on the flipped classroom. The students' survey questionnaire consisted of 14 statements (5-point Likert scale) and 4 open-ended questions. The teachers' survey questionnaire consisted of 20 statements (5-point Likert scale) and 1 open-ended question. The questionnaires were adapted from (Gough et al., 2017; Khodr \& Waller, 2016). The questionnaire's reliability was also tested. The results demonstrate that the questionnaires are reliable since the overall Cronbach Alpha Coefficient of the questionnaires is $(r=0.89)$, which means that the degree of internal consistency is high.

The second method is in-depth interviews. The instrument used was the interview protocol. This in-depth interview was focused on uncovering the strengths and weaknesses of the flipped classroom with CALL. The data from the in-depth interviews were recorded, collected, and transcribed for analysis.

The third method is the tests (pre \& posttest). An essay writing test was given to the students in the pre \& posttest. Before any treatment, the pretest was given at the beginning of the research. Following the flipped classroom with CALL (after a 14-week intervention), the posttest was administered at the end of the research.

\subsection{Data Analysis}

This study had two kinds of data. The data from in-depth interviews were qualitative. In this study, qualitative data were analyzed using Creswell's 
(Creswell, 2012) principles. First, the researcher collected and then prepared the data. This study included creating a general understanding of data, coding the data, and core phenomenon themes. The coding systems were used to gain a more detailed view of events based on the study's purposes. These labeling systems also helped evaluate transcripts of participants.

Besides qualitative data, questionnaires and tests also yielded quantitative data. The quantitative questionnaire data were analyzed using descriptive statistics. Meanwhile, the pre \& posttest data were analyzed using inferential statistics, in this case, using paired sample t-test. The prerequisite tests, i.e., normality and homogeneity testing, were also employed before the paired sample t-test. The program of SPSS 22.0 was used to help analyze the quantitative data.

\section{Results}

\subsection{The Strengths of the Flipped Classroom with CALL in EFL Writing Class}

\subsubsection{Teachers' View}

Based on the results of questionnaire distribution to teachers, it was revealed that flipped classroom integrated with CALL has several advantages, i.e., stimulating learner autonomy, improving teaching and learning process, providing more time to practice EFL writing and giving feedback during a face-to-face meeting, promoting active learning, promoting students' responsibility to learning, promoting peer cooperation and collaboration among students, and so on. Table 2 summarizes the mean and standard deviation from different survey questions related to teachers' responses to the strengths of flipped classroom methodology with CALL in the EFL setting.

Table 2: The Advantages of Flipped Classroom (Teachers' View)

\begin{tabular}{|l|c|c|c|}
\hline \multicolumn{1}{|c|}{ Questions } & N & Mean & SD \\
\hline $\begin{array}{l}\text { The flipped classroom implementation in EFL writing } \\
\text { class helps you improve your teaching process }\end{array}$ & 14 & 4.07 & 0.47 \\
\hline $\begin{array}{l}\text { Implementing the flipped classroom method in EFL } \\
\text { writing class provides more time for writing practice and } \\
\text { giving feedback to students' writing during in-class } \\
\text { activities }\end{array}$ & 14 & 3.64 & 0.93 \\
\hline $\begin{array}{l}\text { Implementing the flipped classroom method in EFL } \\
\text { writing class makes the teaching and learning process } \\
\text { more fun }\end{array}$ & 14 & 3.64 & 0.84 \\
\hline $\begin{array}{l}\text { Implementing the flipped classroom method in EFL } \\
\text { writing class stimulates learner autonomy }\end{array}$ & 14 & 4.36 & 0.74 \\
\hline $\begin{array}{l}\text { Absent students get the benefits of the flipped classroom } \\
\text { method in EFL writing class }\end{array}$ & 14 & 3.07 & 1.14 \\
\hline $\begin{array}{l}\text { Time built for classroom tasks in a flipped classroom } \\
\text { approach enables more writing, peer reviews and active } \\
\text { learning in EFL writing class }\end{array}$ & 14 & 3.71 & 0.47 \\
\hline $\begin{array}{l}\text { EFL learners get the benefits of the flipped classroom } \\
\text { method in EFL writing class }\end{array}$ & 14 & 4.00 & 0.68 \\
\hline $\begin{array}{l}\text { Students do not require the presence of a teacher for basic } \\
\text { teaching, but students need the presence of a teacher to } \\
\text { address issues }\end{array}$ & 14 & 3.07 & 1.07 \\
\hline
\end{tabular}




\begin{tabular}{|l|c|c|c|}
\hline \multicolumn{1}{|c|}{ Questions } & N & Mean & SD \\
\hline $\begin{array}{l}\text { Recorded lessons in the form of video, blogs, or other } \\
\text { online materials help students to learn the lessons every } \\
\text { time and everywhere }\end{array}$ & 14 & 3.86 & 0.53 \\
\hline $\begin{array}{l}\text { Implementing the flipped classroom method in EFL } \\
\text { writing class promotes active learning both in-class and } \\
\text { outside class activities }\end{array}$ & 14 & 3.93 & 0.73 \\
\hline $\begin{array}{l}\text { Implementing the flipped classroom method in EFL } \\
\text { writing class allows teachers more time to personalize } \\
\text { instruction for students }\end{array}$ & 14 & 3.86 & 0.66 \\
\hline EFL learners learn better in a flipped classroom & 14 & 3.43 & 0.76 \\
\hline $\begin{array}{l}\text { Implementing the flipped classroom method in EFL } \\
\text { writing class promotes the students' responsibility for } \\
\text { learning and come prepared to class }\end{array}$ & 14 & 3.64 & 0.74 \\
\hline $\begin{array}{l}\text { The flipped classroom helps students to build stronger } \\
\text { relationships with other students through teamwork and } \\
\text { collaboration }\end{array}$ & 14 & 3.64 & 0.84 \\
\hline $\begin{array}{l}\text { The flipped classroom allows the teachers to have } \\
\text { increased interaction with students }\end{array}$ & 14 & 3.36 & 0.74 \\
\hline
\end{tabular}

Adapted from (Gough et al., 2017; Khodr \& Waller, 2016)

Further, the results of an in-depth interview with teachers also revealed some facts. One of them is that the flipped classroom provides flexibility to teachers in implementing it. They stated that the flipped classroom is helpful for them to improve their teaching and learning practices. The following is the interview excerpt.

"Well, I firstly implemented a flipped classroom last year. At that time, I utilized the google classroom platform in my flipped classroom. Due to its flexibility to implement the teaching and learning process in a flipped classroom context, I continued this method in the following semester. After experiencing it in two semesters, I can conclude that the flipped classroom is helpful for me. My teaching practice is improving significantly. Furthermore, when I implemented a flipped classroom, I also evaluate my students' works. Surprisingly, I could see their learner autonomy was getting improved significantly". (T2)

Besides, in the flipped classroom, the teaching materials are provided in an online form. Therefore, it is always accessible by students everywhere and at any time. For those who do not understand the materials yet, they can access it easily. They can re-watch, re-read, and repeat it as many as they want until they understood it.

"The things that I noticed during the implementation of the flipped classroom in EFL settings were the raise of learner autonomy and students' responsibility for learning and doing tasks, the more time for writing practice and evaluating it, the activeness of students when teaching and learning occurs, the accessible online materials which can facilitate students who do not understand the lesson, and the development of collaboration among students". (T5) 
Another fact about the flipped classroom's strength is that the time management in a face-to-face meeting for EFL writing class is easier than in the traditional classroom. The reason is that in the flipped classroom, the teaching material has already been given through online mode of teaching before the face-to-face meeting occurs. The students can read and understand it before entering the class so that the face-to-face meeting can be focused on writing practice and evaluating students' works.

"Yes, the flipped classroom is very beneficial in teaching EFL writing as we know that teaching EFL writing needs more time for practice and evaluation. In the traditional classroom context, we often find difficulties to manage the time during a face-to-face meeting in the class. After I implemented this method, I mean flipped classroom, I found that time management is no longer a serious problem for me to teach writing. I had already taught the theory through online mode, and the students have already learned the theory before the face-to-face meeting. So, when a faceto-face meeting occurs, we can focus on writing practice and giving feedback to students' tasks". (T6)

\subsubsection{Students' View}

Another questionnaire dealing with flipped classroom advantages and disadvantages integrated with CALL was also distributed to students. From the questionnaire, the students confirmed that flipped classroom has some advantages for them, i.e., raising students' motivation to learning, providing more time for writing practice, raising students' engagement, and giving benefit to students' future since they can learn both the knowledge and information technology during flipped classroom process. Table 3 summarizes the mean and standard deviation from different survey questions related to students' responses to the strengths of flipped classroom methodology with CALL in the EFL setting.

Table 3: The Advantages of Flipped Classroom (Students' View)

\begin{tabular}{|l|c|c|c|}
\hline \multicolumn{1}{|c|}{ Questions } & N & Mean & SD \\
\hline $\begin{array}{l}\text { I am more inspired to practice EFL writing in the Flipped } \\
\text { Classroom }\end{array}$ & 150 & 3.96 & 0.20 \\
\hline $\begin{array}{l}\text { I have more time to practice EFL writing at a Flipped } \\
\text { Classroom }\end{array}$ & 150 & 3.96 & 0.26 \\
\hline I want to watch the video lessons & 150 & 3.98 & 0.27 \\
\hline $\begin{array}{l}\text { I have more time to do class exercises in the Flipped } \\
\text { Classroom }\end{array}$ & 150 & 3.97 & 0.23 \\
\hline $\begin{array}{l}\text { I am able to communicate more with other students in the } \\
\text { Flipped Classroom }\end{array}$ & 150 & 3.97 & 0.23 \\
\hline $\begin{array}{l}\text { I would benefit from learning to use a flipped classroom in } \\
\text { my future education }\end{array}$ & 150 & 4.01 & 0.12 \\
\hline $\begin{array}{l}\text { I use online services such as YouTube, weblogs on a daily } \\
\text { basis }\end{array}$ & 150 & 3.95 & 0.24 \\
\hline $\begin{array}{l}\text { The Flipped classroom is more appealing than conventional } \\
\text { teaching }\end{array}$ & 150 & 3.93 & 0.34 \\
\hline I see the video assignment occasionally & 150 & 3.96 & 0.23 \\
\hline $\begin{array}{l}\text { Flipped Classroom will give me experience for my future, } \\
\text { e.g., for job training }\end{array}$ & 150 & 3.97 & 0.20 \\
\hline
\end{tabular}

Adapted from (Gough et al., 2017; Khodr \& Waller, 2016) 
An in-depth interview was also had been conducted with students to reveal students' perceptions about the advantages of the flipped classroom. The interview confirmed that flipped classrooms could build up their learning motivation because the teaching materials were presented interestingly. They also stated that a flipped classroom is a fun but challenging methodology.

"The integration of face-to-face and online learning is such a kind of motivation for me to learn EFL writing. We can learn the material anywhere and at any time. It's so flexible. Moreover, the materials are presented in an interesting way, such as video, weblogs, etc. It is enjoyable but challenging". (S5)

The integration of technology during the teaching and learning process, in the flipped classroom, also benefits the stduents. They can get the knowledge, and at the same time, they learn information technology, which could benefit them shortly.

"Well, I think the integration of technology in this method is an added value for students. We are required to learn by utilizing technology. It means that we also learn how to use the technology itself. This is, of course, will benefit us in our future". (S6)

The flexibility to access the online materials is also one of the advantages of flipped classroom confirmed by students. The video materials allow students to quickly stop, re-watch, pause, and repeat the part(s) they do not understand yet.

"The application of the flipped classroom model has many advantages over the traditional learning model. The availability of the material in the form of videos gives students the freedom to stop or repeat the material at any time in parts they do not understand". (S9)

Further, team-work among students can also be promoted through a flipped classroom activity. They can cooperate with their peers to learn, do the tasks, and even peer-evaluate their works.

"A flipped classroom enables students to spend more time collaborating. This is not only a great way to learn, but also good for their team working skills. Further, it allows for self-paced learning, diving deeper into the subject, being better prepared, reusing lectures, and creating transparency for parents". (S10)

\subsection{The Weaknesses of the Flipped Classroom with CALL in EFL Writing Class}

\subsubsection{Teachers' View}

Aside from the flipped classroom's advantages mentioned in the preceding part, there are also some disadvantages of the flipped classroom with CALL. From the questionnaire distributed to teachers, it was revealed that the advantages of the flipped classroom are the need of more time for material preparation and technological problems faced by some students who are not familiar with the platform used. 
Table 4: The Disadvantages of Flipped Classroom (Teachers' View)

\begin{tabular}{|l|c|c|c|}
\hline \multicolumn{1}{|c|}{ Questions } & N & Mean & SD \\
\hline $\begin{array}{l}\text { Implementing the flipped classroom method in EFL writing } \\
\text { class needs more time to prepare teaching materials }\end{array}$ & 14 & 4.21 & 0.80 \\
\hline $\begin{array}{l}\text { Some students face difficulties during the implementation of } \\
\text { the flipped classroom method in EFL writing class due to the } \\
\text { use of technology required outside of school }\end{array}$ & 14 & 3.29 & 1.07 \\
\hline
\end{tabular}

Adapted from (Gough et al., 2017; Khodr \& Waller, 2016)

The teachers also confirmed the questionnaire distribution findings related to flipped classrooms' drawbacks during the in-depth interview. It was stated that material preparation in a flipped classroom setting is time-consuming. They must at least record a video lesson for each meeting so that the students can learn the material through the LMS.

"Well, if we want to implement a flipped classroom method, we need more time for material preparation. It is time-consuming. We must make a video lesson and upload it to the LMS for each meeting. However, once we have finished preparing the materials, the teaching-learning process will run effectively". (T11)

Another drawback of the flipped classroom is technological problems and the availability of technology devices students face. Not all students were familiar with the platform used in online learning, so they found difficulties utilizing it. Further, a few students also do not have their laptops and internet connection in their homes.

"Based on my experience, the technological issue is one of the problems in my class. Some students were unfamiliar with a certain platform. So, we need to explain to them how to utilize the platform in order to make the teaching and learning process run smoothly". (T13)

"There are drawbacks, such as not all students have access to the required information technology devices, such as computers/laptops and internet connections. This happens in my class. Further, it is also time-consuming for preparing the materials, and sometimes it is exhausting". (T14)

\subsubsection{Students' View}

The questionnaire distributed to students also revealed the drawbacks of the flipped classroom. Even though only a few students confirmed the flipped classroom's drawbacks, it still needs to be exposed. The drawbacks stated by the students were that a few students were not familiar with the use of social media in the teaching and learning process. Consequently, they got difficulties in utilizing it. This leads to students' frustration in learning, and they prefer to traditional learning to flipped classroom. 
Table 5: The Disadvantages of Flipped Classroom (Students' View)

\begin{tabular}{|l|c|c|c|}
\hline \multicolumn{1}{|c|}{ Questions } & N & Mean & SD \\
\hline The Flipped Classroom did not boost my EFL writing skill & 150 & 2.33 & 0.51 \\
\hline I would not suggest a friend to the Flipped classroom & 150 & 2.01 & 0.16 \\
\hline $\begin{array}{l}\text { Internet networking is not an important part of my learning } \\
\text { (YouTube, Twitter, Facebook) }\end{array}$ & 150 & 2.02 & 0.24 \\
\hline $\begin{array}{l}\text { I like to see a conventional lesson led by teachers instead of a } \\
\text { video }\end{array}$ & 150 & 2.11 & 0.44 \\
\hline
\end{tabular}

Adapted from (Gough et al., 2017; Khodr \& Waller, 2016)

Meanwhile, in-depth interview with students revealed that the flipped classroom causes problems for those who do not have internet connection and data packages. Further, for low-motivated students, online learning makes them demotivated in some cases because they were required to have a high commitment to learning.

"During online learning, it requires a good internet connection and surely data package, for some students, this is a problem. So, the teacher should accommodate such conditions to guarantee that teaching and learning process could run well". (S11)

"For low-motivated students, this online learning will burden them. Consequently, they will be left behind. Therefore, the teacher should always maintain their students' progress and motivate them". (S13)

\subsubsection{The Effectiveness of the Flipped Classroom with CALL in EFL Writing Class}

The one group pretest and posttest design were analyzed in this part. The paired sample t-test was carried out to determine whether or not there was a significant difference in EFL students' writing performance before and after implementing the flipped classroom. Before the paired sample t-test was carried out, two prerequisite tests, i.e., normality and homogeneity tests, were also conducted to the pre-and-post test scores. Then, after the paired sample t-test was performed, the N-Gain score was calculated. The normality test results using Saphiro-Wilk (analyzed through SPSS 22.0) revealed that the data were in a normal distribution (see Table 6). Further, the homogeneity test using the Levene Test (analyzed through SPSS 22.0) revealed that the data were homogeneous (see Table 7).

Table 6: The Summary of Normality Test Results

\begin{tabular}{|c|c|c|c|c|c|c|}
\hline \multirow{2}{*}{\multicolumn{2}{|c|}{ Research Site }} & \multicolumn{3}{|c|}{ Saphiro-Wilk } & \multirow{3}{*}{$\begin{array}{c}\alpha \\
.05\end{array}$} & \multirow{2}{*}{ Conclusion } \\
\hline & & \multirow{2}{*}{$\begin{array}{r}\text { Statistic } \\
.948\end{array}$} & \multirow{2}{*}{$\begin{array}{r}\mathbf{d f} \\
30\end{array}$} & \multirow{2}{*}{$\begin{array}{c}\text { Sig. } \\
.145\end{array}$} & & \\
\hline $1^{\text {st }}$ University & Pre-test & & & & & \multirow{5}{*}{ 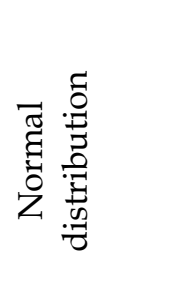 } \\
\hline & Post-test & 955 & 30 & .234 & .05 & \\
\hline \multirow[t]{2}{*}{$2^{\text {nd }}$ University } & Pre-test & 964 & 30 & 396 & .05 & \\
\hline & Post-test & 963 & 30 & 367 & .05 & \\
\hline $3^{\text {rd }}$ University & Pre-test & .968 & 30 & .474 & .05 & \\
\hline
\end{tabular}




\begin{tabular}{|l|l|r|r|r|r|}
\hline & Post-test & .949 & 30 & $\mathbf{. 1 5 6}$ & $\mathbf{. 0 5}$ \\
\hline $4^{\text {th }}$ University & Pre-test & .968 & 30 & $\mathbf{. 4 7 4}$ & $\mathbf{. 0 5}$ \\
\cline { 2 - 6 } & Post-test & .956 & 30 & $\mathbf{. 2 4 8}$ & $\mathbf{. 0 5}$ \\
\hline \multirow{2}{*}{$5^{\text {th }}$ University } & Pre-test & .960 & 30 & $\mathbf{. 3 0 5}$ & $\mathbf{. 0 5}$ \\
\cline { 2 - 6 } & Post-test & .948 & 30 & $\mathbf{. 1 4 8}$ & $\mathbf{. 0 5}$ \\
\hline
\end{tabular}

Table 7: The Summary of Homogeneity Test Results

\begin{tabular}{|c|c|c|c|c|c|c|}
\hline Research Site & $\begin{array}{l}\text { Levene } \\
\text { Statistic }\end{array}$ & df1 & df2 & Sig. & a & Conclusion \\
\hline $1^{\text {st }}$ University & .060 & 1 & 58 & .808 & .05 & \multirow{5}{*}{ Homogeneous } \\
\hline $2^{\text {nd }}$ University & .040 & 1 & 58 & .842 & .05 & \\
\hline $3^{\text {rd }}$ University & .241 & 1 & 58 & .625 & .05 & \\
\hline $4^{\text {th }}$ University & .162 & 1 & 58 & .689 & .05 & \\
\hline $5^{\text {th }}$ University & .002 & 1 & 58 & .964 & .05 & \\
\hline
\end{tabular}

After the data were tested for their normality and homogeneity, the next step was paired sample t-test. It was done whether there is a significant difference between the mean of pretest scores and posttest scores. The following is the result of the paired sample t-test.

Table 8: The Summary of Paired Sample t-test Results

\begin{tabular}{|c|c|c|c|c|c|c|c|c|c|}
\hline \multirow{3}{*}{\multicolumn{2}{|c|}{ Research Site }} & \multicolumn{5}{|c|}{ Paired Differences } & \multirow{3}{*}{$\mathbf{t}$} & \multirow{3}{*}{ df } & \multirow{3}{*}{$\begin{array}{l}\text { Sig. (2- } \\
\text { tailed) }\end{array}$} \\
\hline & & \multirow[b]{2}{*}{ Mean } & \multirow{2}{*}{$\begin{array}{c}\text { Std. } \\
\text { Deviation }\end{array}$} & \multirow{2}{*}{$\begin{array}{l}\text { Std. } \\
\text { Error } \\
\text { Mean }\end{array}$} & \multicolumn{2}{|c|}{$\begin{array}{l}\text { 95\% Confidence } \\
\text { Interval of the } \\
\text { Difference } \\
\end{array}$} & & & \\
\hline & & & & & Lower & Upper & & & \\
\hline $\begin{array}{c}1^{\text {st }} \\
\text { University }\end{array}$ & \begin{tabular}{|l} 
Pre- \\
post \\
test
\end{tabular} & -19.45000 & 4.44381 & .81132 & -21.10934 & -17.79066 & -23.973 & 29 & .000 \\
\hline $\begin{array}{c}2^{\text {nd }} \\
\text { University }\end{array}$ & $\begin{array}{l}\text { Pre- } \\
\text { post } \\
\text { test }\end{array}$ & -19.45000 & 4.27976 & .78137 & -21.04809 & -17.85191 & -24.892 & 29 & .000 \\
\hline $\begin{array}{c}3^{\text {rd }} \\
\text { University }\end{array}$ & $\begin{array}{l}\text { Pre- } \\
\text { post } \\
\text { test }\end{array}$ & -19.43333 & 4.24210 & .77450 & -21.01736 & -17.84931 & -25.092 & 29 & .000 \\
\hline $\begin{array}{c}4^{\text {th }} \\
\text { University }\end{array}$ & $\begin{array}{l}\text { Pre- } \\
\text { post } \\
\text { test }\end{array}$ & -19.36667 & 4.07882 & .74469 & -20.88972 & -17.84361 & -26.006 & 29 & .000 \\
\hline $\begin{array}{c}5^{\text {th }} \\
\text { University }\end{array}$ & $\begin{array}{l}\text { Pre- } \\
\text { post } \\
\text { test }\end{array}$ & -19.16667 & 4.17986 & .76314 & -20.72745 & -17.60588 & -25.116 & 29 & .000 \\
\hline
\end{tabular}

Table 8 shows the results of the paired sample t-test. It reveals that the Sig. (2tailed), in each university group $(\mathrm{p}=.000, \mathrm{p}<.05)$, which means that there is a statistically significant difference in students' EFL writing performance before and after the intervention (flipped classroom). 
After knowing that there is a significant difference in students' EFL writing performance before and after the flipped classroom (analyzed by paired sample t-test), the N-Gain score was calculated (by calculating the difference between the pretest and posttest scores). The N-Gain score calculation was done to know how effective the flipped classroom implemented in teaching EFL writing. The results are presented in Table 9.

$$
N-\text { Gain Score }=\frac{\text { Posttest Score }- \text { Pretest Score }}{\text { Maximum Score }- \text { Pretest Score }}
$$

Figure 1: The Formula of Calculation N-Gain Score

Table 9: The Summary of N-Gain Score

\begin{tabular}{|c|c|c|}
\hline Research Site & N-Gain Score & Conclusion \\
\hline $1^{\text {st }}$ University & 0.57 & \multirow{3}{*}{ Moderately Effective } \\
\hline $2^{\text {nd }}$ University & 0.58 & \\
\hline $3^{\text {rd }}$ University & 0.57 & \\
\hline $4^{\text {th }}$ University & 0.57 & \\
\hline $5^{\text {th }}$ University & 0.57 & \\
\hline
\end{tabular}

Table 9 above shows that the N-Gain score for each university group is in the range of $0.3<\mathrm{g}<0.7$ (moderate). Therefore, it is concluded that the flipped classroom's implementation in EFL writing class is moderately effective.

\section{Discussion}

5.1. What are the strengths of the flipped classroom with CALL in the EFL writing class?

The findings of this study revealed that flipped classroom with CALL in EFL writing class has several advantages, such as stimulating learner autonomy, improving teaching and learning process, providing more time to practice EFL writing and giving feedback during a face-to-face meeting, promoting active learning, promoting students' responsibility to learning, promoting peer cooperation and collaboration among students, providing flexibility to teachers and students in teaching and learning process, raising students' motivation to learning, engaging students in teaching and learning process, and giving benefit to students' future for they can learn both the knowledge and information technology during flipped classroom process.

Even though, there are some benefits of the flipped classroom, but it also has some weaknesses (Uzunboylu \& Karagozlu, 2015). In this sense, the flipped classroom can generate higher learning. In the flipped classroom, students may either watch a video, read a paper or complete their own computerized module (Moffett, 2015). The lower stages of Bloom's taxonomy, comprehension, is performed outside school (Uzunboylu \& Karagozlu, 2015). Meanwhile, in the classroom, the teachers and learners are engaged in higher-level activities of Bloom's Taxonomy stages, i.e., application, analysis, and synthesis skills.

Furthermore, the flipped classroom makes for more possibilities for self-centered instruction, as teaching accompanied by practicing will become self-learning 
before practice. This raises self-trust and makes learning more self-regulated (Juan, 2020; Strayer, 2012; Zarouk, Olivera \& Khald , 2020). This usually consists of flipping around the classroom work with content assigned as homework (Gilboy, Heinerichs \& Pazzaglia, 2015). In addition, the improvement of learner-centered teaching in a flipped learning will enhance the autonomy of a learner by encouraging new learning methods to be more broadly applied than standard methods, thus helping to accommodate the various types of learning among students (Uzunboylu \& Karagozlu, 2015). Students are allowed to take the solution that better matches their academic needs. They will think much more about material which in turn encourage them to take part in solving problems (Mehring, 2016). Therefore, this method progresses to a higher degree than traditional learning.

Touchton (2015) also stressed this feature of the flipped classroom. it makes learning more fun and attracts to learners. They may also revisit the content they want to learn and re-use it. In addition, learners will obtain a good experience of learning by themselves and examine new content and recognize information gaps before face-to-face classroom time. Then, in the class, teachers and students discuss the material (Mehring, 2016). Moreover, in the flipped classroom, learners can collaborate with peers and benefit from their experience. Touchton (2015) suggests that when learners operate in groups, the flipped classroom encourages peer-instruction, whereby informal interactions help sustain development while the teacher is busy delivering individualized instruction elsewhere. Thus, students should educate one another to reach comprehensive interpretation of the subject.

Another benefit is that teachers can adjust approaches to redirect the classroom based on learners' criteria by, for example, viewing videos and collaboration among students (Touchton, 2015). This guidance lets teachers identify and encourage those students who need to be more focused and spend more time, such as students with online difficulties (Moffett, 2015). They will also be able to give more comprehensive input to learners to focus on their deficiency areas and try to fix them (Touchton, 2015). This timely feedback in the face-to-face classroom can be difficult because of the time constraints, but it can be solved by using online resources. While this illustrates the impact on instruction of the flipped classroom, it also has implications for the abilities of teachers. It facilitates information exchange and enhances the resources of teachers (Uzunboylu \& Karagozlu, 2015).

\subsection{What are the weaknesses of the flipped classroom with CALL in the EFL writing class?}

Apart from the flipped classroom's advantages described in the preceding section, the flipped classroom with CALL also has some disadvantages. It was revealed that the advantages of the flipped classroom bring up the issues of more time needed in material preparation and technological problems faced by some students who are not familiar with the platform used. Besides, the flipped classroom causes problems for those who do not have an internet connection and data package. Further, for low-motivated students, online learning makes them demotivated in some cases because they were required to have a high commitment to learning. 
Learners may face additional problems with their technology skills. In reality, Engin (2014) points out that the possibility that students may not be able to cope with the technologies involved, is one of the biggest problems in this flipped classroom model. The provision of a trial session to learners will, therefore, help to address this challenge. However, the use of computer in teaching and learning process takes more time (Hoic-Bozic, Mornar \& Boticki, 2009). Although online devices can allow students to share their content with peers and teachers, it still needs supervision to the students (Engin, 2014). It is because the students are physically and mentally remote. Moreover, teachers' workload will increase if they make their own videos, trying to create decent videos of appropriate quality (Hoic-Bozic et al., 2009). Therefore, they would not be able to apply to a flipped classroom (Hoic-Bozic et al., 2009). Moreover, creating activities using online tools can be challenging for a teacher, and learners' access can be a problem because they need online access to display online content, and teachers may need to learn relevant technical skills for designing the learning materials.

\subsection{Is there any significant difference in students' EFL writing performance before and after implementing the flipped classroom with CALL?}

The results of the paired sample test reveal that the Sig. (2-tailed), in each university group $(\mathrm{p}=.000, \mathrm{p}<.05)$, which means that there is a statistically significant difference in students' EFL writing performance before and after the intervention (flipped classroom). Further, it is also revealed that the N-Gain score for each university group is in the range of $0.3<\mathrm{g}<0.7$ (moderate). Therefore, it is concluded that the flipped classroom's implementation in EFL writing class is moderately effective.

Hung (2015) analyzed the flipped classroom effect on a general English course involving 75 EFL students. The study was performed in Taiwan, where for six consecutive weeks, the researcher applied a flipped-classroom approach. The teacher prepared and distributed online material through WebQuest. Using a quasi-experimental design, administered the only posttest, the findings showed improvement in learning.

More recently, researchers introduced a flipped classroom in Taiwan with 40 high school students in a study conducted by Huang \& Hong (2016). They were selected randomly to undergo 12 hours of flipped classroom instruction. Another 37 participants entered a control group. This experimental design assessed the effect of the flipped classroom on reading comprehension and ICT literacy. The study revealed improvement skills, and students showed positive attitudes towards this instruction. Implementing the flipped classroom in the sense of the current study may have a positive effect on EFL courses.

\section{Conclusion}

The results of this study revealed that flipped classroom with CALL in EFL writing class has many advantages, such as stimulating learner autonomy, improving teaching and learning processes, providing more time for EFL writing and input during face-to-face meetings, promoting active learning, promoting student learning responsibility, and promoting peer collaboration. Besides, some 
drawbacks were also found from its implementation. It was revealed that the advantages of the flipped classroom are the need for more time to prepare materials and technical challenges faced by certain students who are unfamiliar with the platform used. The flipped classroom also poses some problems for those without internet access and data packages. Furthermore, online learning makes them demotivated in some cases for low-motivated students because they needed a high commitment to learning. However, implementing the flipped classroom in the current study's context positively affects the EFL writing course. This study has implications for EFL writing teachers, mostly dealing with the preparation of the materials. Teachers should provide online materials such as videos from trusted sources or, if possible, they can make these videos learning materials. This can convince the students of the need to watch videos.

\section{Acknowledgement}

This research is fully funded by the Ministry of Research and Technology/National Research and Innovation Agency (Indonesia) on Fundamental Research scheme (Penelitian Dasar) of the year 2020.

\section{References}

Adnan, M. (2017). Perceptions of senior-year ELT students for flipped classroom: a materials development course. Computer Assisted Language Learning, 30(3-4), 204222. https://doi.org/10.1080/09588221.2017.1301958

Ahmad, S. Z. (2016). The flipped classroom model to develop Egyptian EFL students' listening comprehension. English Language Teaching, 9(9), 166. https:// doi.org/10.5539/elt.v9n9p166

Al-Harbi, S. S., \& Alshumaimeri, Y. A. (2016). The flipped classroom impact in grammar class on EFL saudi secondary school students' performances and attitudes. English Language Teaching, 9(10), 60. https://doi.org/10.5539/elt.v9n10p60

Alhasani, H., Masood, M., \& Wan, F. (2018, April). The impact of computer assisted language learning on ESL students' reading engagement skill in the flipped classroom. Ireland International Conference on Education (IICE-2018) [Conference presentaion], pp. 143-148. Dublin, Ireland.

Alsowat, H. (2016). An EFL flipped classroom teaching model: Effects on English language higher-order thinking skills, student engagement and satisfaction. Journal of Education and Practice, 7(9), 108-121.

Amiryousefi, M. (2017). The incorporation of flipped learning into conventional classes to enhance EFL learners' L2 speaking, L2 listening, and engagement. Innovation in Language Learning and Teaching, 1-15. https:// doi.org/10.1080/17501229.2017.1394307

Ansori, M., \& Nafi', N. N. (2018). English teachers' perceived benefits and challenges of flipped classroom implementation. JEELS, 5(2), 211-227.

Arifani, Y. (2019). The application of small whatsapp groups and the individual flipped instruction model to boost EFL learners' mastery of collocation. CALL-EJ, 20(1), 52-73.

Basal, A. (2015). The implementation of a flipped classroom in foreign language teaching. Turkish Online Journal of Distance Education, 16(4), 28-37. https://files.eric.ed.gov/fulltext/EJ1092800.pdf

Bergmann, J., \& Sams, A. (2012). Flip your classroom: Reach every student in every class every day. International Society for Technology in Education.

Boyraz, S., \& Ocak, G. (2017). Implementation of flipped education into Turkish EFL 
teaching context. Journal of Language and Linguistics Studies, 13(2), 426-439.

Chen Hsieh, J. S., Wu, W. C. V., \& Marek, M. W. (2017). Using the flipped classroom to enhance EFL learning. Computer Assisted Language Learning, 30(1-2), 1-21. https:// doi.org/10.1080/09588221.2015.1111910

Choe, E., \& Seong, M.-H. (2016). A case study of the flipped classroom in a Korean university general English course. Journal of Pan-Pacific Association of Applied Linguistics, 20(2), 71-93.

Chuang, H. H., Weng, C. Y., \& Chen, C. H. (2018). Which students benefit most from a flipped classroom approach to language learning? British Journal of Educational Technology, 49(1), 56-68. https:/ / doi.org/10.1111/bjet.12530

Creswell, J. W. (Ed.). (2012). Educational research: Planning, conducting and evaluating quantitative and qualitative research (4th ed.). Pearson Education Inc.

Creswell, J. W., \& Clark, V. L. P. (Eds.). (2011). Designing and conducting mixed methods research ( $2^{\text {nd }}$ ed.). Sage Publications Ltd.

Doman, E., \& Webb, M. (2017). The flipped experience for Chinese university students studying English as a foreign language. TESOL Journal, 8(1), 102-141. https://doi.org/10.1002/tesj.264

Egbert, J., Herman, D., \& Lee, H. (2015). Flipped instruction in English language teacher education: A design-based study in a complex, open-ended learning environment. Tesl-Ej, 19(2), 1-23.

Ekmekci, E. (2017). The flipped writing classroom in Turkish EFL context: A comparative study on a new model. Turkish Online Journal of Distance Education, 18(2), 151-167.

Engin, M. (2014). Extending the flipped classroom model: Developing second language writing skills through student-created digital videos. Journal of the Scholarship of Teaching and Learning, 14(5). https:// doi.org/10.14434/12829

Francl, T. (2014). Is flipped learning appropriate? Journal of Research in Innovative Teaching, $7(1), 119-128$.

Gasmi, A. A. (2017). An exploratory study of students' lived experiences in a blendedflipped writing class. SSRN Electronic Journal, 3, 210-226. https://doi.org/10.2139/ssrn.2822993

Ghufron, M. A., \& Nurdianingsih, F. (2019). Flipped teaching with call in EFL writing class: How does it work and affect learner autonomy? European Journal of Educational Research, 8(4), 983-997. https://doi.org/10.12973/eu-jer.8.4.983

Ghufron, M. A., \& Nurdianingsih, F. (2020). Flipped teaching with call media in EFL writing course: Indonesian EFL writing teachers' reflection. Pertanika Journal of Social Sciences and Humanities, 28(2), 1-18.

Gilboy, M. B., Heinerichs, S., \& Pazzaglia, G. (2015). Enhancing student engagement using the flipped classroom. Journal of Nutrition Education and Behavior, 47(1), 109-114. https://doi.org/10.1016/j.jneb.2014.08.008

Gough, E., DeJong, D., Grundmeyer, T., \& Baron, M. (2017). K-12 teacher perceptions regarding the flipped classroom model for teaching and learning. Journal of Educational Technology Systems, 45(3), 390-423. https://doi.org/10.1177/0047239516658444

Han, Y. (2015). Successfully flipping the ESL classroom for learner autonomy. NYS Tesol Journal, 2(1), 98-109.

Hoic-Bozic, N., Mornar, V., \& Boticki, I. (2009). A blended learning approach to course design and implementation. IEEE Transactions on Education, 52(1), 19-30. https://doi.org/10.1109/TE.2007.914945

Huang, Y. N., \& Hong, Z. R. (2016). The effects of a flipped English classroom intervention on students' information and communication technology and English reading 
comprehension. Educational Technology Research and Development, 64(2), 175-193. https:// doi.org/10.1007/s11423-015-9412-7

Hung, H. T. (2015). Flipping the classroom for English language learners to foster active learning. Computer Assisted Language Learning, 28(1), 81-96. https://doi.org/10.1080/09588221.2014.967701

Jafarian, K., Soori, A., \& Kafipour, R. (2012). The effect of computer assisted language learning (CALL) on EFL high school students' writing achievement. European Journal of Social Sciences, 27(2), 138-148.

Juan, C. (2020). SPOC-based flipped learning model applied in interpreting teaching. International Journal of Emerging Technologies in Learning, 15(17), 4-13. https://doi.org/10.3991/ijet.v15i17.14581

Kang, N. (2015). The comparison between regular and flipped classrooms for EFL Korean adult learners. Multimedia-Assisted Language Learning, 18(3), 41-72. https:// doi.org/10.15702/mall.2015.18.3.41

Karabulut-Ilgu, A., Jaramillo Cherrez, N., \& Jahren, C. T. (2018). A systematic review of research on the flipped learning method in engineering education. British Journal of Educational Technology, 49(3), 398-411. https://doi.org/10.1111/bjet.12548

Khodr, M., \& Waller, L. (2016). Analysis of engineering students' responses to flipped classroom methodology in the United Arab Emirates. Asian Social Science, 12(2), 93-98. https://doi.org/10.5539/ass.v12n2p93

Khosravani, M., Khoshsima, H., \& Mohamadian, A. (2020). On the effect of flipped classroom on learners' achievement, autonomy, Motivation and WTC: Investigating learning and learner variables. Journal of English Language Teaching and Learning, 12(25), 175-189.

Köroğlu, Z. Ç., \& Çakır, A. (2017). Implementation of flipped instruction in language classrooms : An alternative way to develop speaking skills of pre-service English language teachers Zeynep Çetin Köroğlu Abdulvahit Çakır Gazi University , Turkey. International Journal of Education and Development, 13(2), 42-55.

Mehring, J. (2016). Present research on the flipped classroom and potential tools for the EFL classroom. Computers in the Schools, 33(1), 1-10. https://doi.org/10.1080/07380569.2016.1139912

Meléndez, L., \& Iza, S. (2017). Application of the Flipped Classroom methodology in a virtual platform for teaching English language grammar in level B1. Revista Publicando, 4(12), 236-246.

Mo, J., \& Mao, C. (2017). An Empirical Study on the Effectiveness of Content-based Instruction in the Chinese College English Context. Revista de La Facultad de Ingenieria U. C. V, 32(10), 632-639.

Moffett, J. (2015). Twelve tips for flipping the classroom. Medical Teacher, 37(4), 331-336. https://doi.org/10.3109/0142159X.2014.943710

Purcell, K., Buchanan, J., \& Friedrich, L. (2013). The impact of digital tools on student writing and how writing is taught in schools [Report pp. 1-114]. The National Writing Project. http:// pewinternet.org/Reports/2013/Teacherstechnology-and-writing

Rahimi, M., \& Hosseini K., S. F. (2011). The impact of computer-based activities on Iranian high-school students' attitudes towards computer-assisted language learning. Procedia Computer Science, 3, 183-190. https://doi.org/10.1016/j.procs.2010.12.031

Rahmelina, L., Firdian, F., Maulana, I. T., \& Aisyah, H. (2019). The effectiveness of the flipped classroom model using e-learning media in introduction to information technology course. International Journal of Emerging Technologies in Learning (IJET), 14(21), 148-162.

Soltanpour, F., \& Valizadeh, M. (2018). A flipped writing classroom: Effects on EFL 
learners' argumentative essays. Advances in Language and Literary Studies, 9(1), 513.

Strayer, J. F. (2012). How learning in an inverted classroom influences cooperation, innovation and task orientation. Learning Environments Research, 15(2), 171-193. https://doi.org/10.1007/s10984-012-9108-4

Su Ping, R. L., Verezub, E., Adi Badiozaman, I. F. bt., \& Chen, W. S. (2019). Tracing EFL students' flipped classroom journey in a writing class: Lessons from Malaysia. Innovations in Education and Teaching International, 1-12. https:// doi.org/10.1080/14703297.2019.1574597

Sung, K. (2015). A case study on a flipped classroom in an EFL content course. MultimediaAssisted Language Learning, 18(2), 159-187.

Suranakkharin, T. (2017). Using the flipped model to foster Thai learners' second language collocation knowledge. 3L: Language, Linguistics, Literature, 23(3), 1-20. https://doi.org/10.17576/3L-2017-2303-01

Talebinezhad, M. R., \& Abarghoui, M. A. (2013). The Iranian high school students' attitude toward CALL and the use of CALL for EFL receptive skills. Theory and Practice in Language Studies, 3(2), 329-337. https://doi.org/10.4304/tpls.3.2.329-337

Touchton, M. (2015). Flipping the Classroom and Student Performance in Advanced Statistics: Evidence from a Quasi-Experiment. Journal of Political Science Education, 11(1), 28-44. https://doi.org/10.1080/15512169.2014.985105

Turan, Z., \& Akdag-Cimen, B. (2019). Flipped classroom in English language teaching: a systematic review. Computer Assisted Language Learning, 1-17. https://doi.org/10.1080/09588221.2019.1584117

Turan, Z., \& Göktaş, Y. (2018). Innovative redesign of teacher education ICT courses: How flipped classrooms impact motivation? Journal of Education and Future, 7(13), 133144.

Uzunboylu, H., \& Karagozlu, D. (2015). Flipped classroom: A review of recent literature. $\begin{array}{lllll}\text { World Journal on Educational Technology, } & 7(2), & 142 .\end{array}$ https://doi.org/10.18844/wjet.v7i2.46

Vaezi, R., Afghari, A., \& Lotfi, A. (2019). Investigating listening comprehension through flipped classroom approach: Does authenticity matter? CALL-EJ, 20(1), 178-208.

Webb, M., \& Doman, E. (2020). Impacts of flipped classrooms on learner attitudes towards technology-enhanced language learning. Computer Assisted Language Learning, 33(3), 240-274. https:// doi.org/10.1080/09588221.2018.1557692

Webb, M., Doman, E., \& Pusey, K. (2014). Flipping a Chinese university EFL course: What students and teachers think of the model. The Journal of Asia TEFL, 11(4), 53-87.

Wisdom, J., \& Creswell, J. W. (2013). Integrating quantitative and qualitative data collection and analysis while studying patient-centered medical home models. Agency for Healthcare Reseach and Quality, 13, 1-5. https:/ / doi.org/No. 13-0028-EF.

Yang, C. C. R. (2017). An investigation of the use of the "flipped classroom" pedagogy in secondary English language classrooms. Journal of Information Technology Education: Innovations in Practice, 16(1), 1-20.

Yu, Z., \& Wang, G. (2016). Academic achievements and satisfaction of the Clicker-aided flipped business English writing class. Educational Technology \& Society, 19(2), 298312.

Zainuddin, Z. (2017). First-year college students' experiences in the EFL flipped classroom: A case study in Indonesia. International Journal of Instruction, 10(1), 133150.

Zainuddin, Z., \& Perera, C. J. (2017). Exploring students' competence, autonomy and relatedness in the flipped classroom pedagogical model. Journal of Further and Higher Education, 43(1), 115-126. https:/ / doi.org/10.1080/0309877X.2017.1356916 
Zarouk, M. Y., Olivera, E., \& Khaldi, M. (2020). The impact of flipped project-based learning on self-regulation in higher education. International Journal of Emerging Technologies in Learning, 15(17), 127-147. https://doi.org/10.3991/ijet.v15i17.14135

Zhang, F. (2017). Quality-improving strategies of college English teaching based on microlesson and flipped classroom. English Language Teaching, 10(5), 243. https://doi.org/10.5539/elt.v10n5p243

Zou, D., \& Xie, H. (2019). Flipping an English writing class with technology-enhanced justin-time teaching and peer instruction. Interactive Learning Environments, 27(8), 1127-1142. https://doi.org/10.1080/10494820.2018.1495654 